\title{
THE EFFECT OF GOOD CORPORATE GOVERNANCE AND TAX PLANNING ON COMPANY VALUE
}

\author{
Angga Hidayat ${ }^{*}$, Nike Yuliah \\ University of Pamulang \\ *angga1203hidayat@gmail.com
}

\begin{abstract}
This study aims to analyze the influence of Good Corporate Governance and tax planning on corporate value. This research is a type of quantitative research. The type of data used is secondary data obtained from www.idx.co.id and the company's website. The analytical method used is multiple regression analysis using SPSS version 22 software. The population in this study are manufacturing companies listed on the Indonesia Stock Exchange during the period 2013-2017. While the sample of this study was determined by purposive sampling method to obtain a total of 105 data that could be processed.Based on the results of good corporate governance regression analysis which is represented by institusional ownership proxy has a significant effect on firm value and tax planning has a significant effect on firm value.
\end{abstract}

Keywords: Good Corporate Governance, Tax Planning, corporate value.

\section{INTRODUCTION}

The rapid competition among companies has changed the current era of globalization, each company will attempt to achieve the goal of increasing the value of the company. the purpose of establishing a company is to make a profit. The company's management strives so that the goals can be achieved because, whether good or bad management performance, the greater the profit generated, the greater the profit gained, the more it will attract investors to invest.

Companies that have high corporate value can increase shareholder prosperity, so that shareholders can invest their capital into the company. With the increasing competition, it is expected that the company will be able to run in balance by taking into account Good Corporate Governance.
The establishment of a company must have a clear goal, there are several goals for the establishment of a company. The first goal is to achieve maximum profit.

Based on the background and previous studies, there are inconsistent results, where there are studies that find there is or no influence of tax planning, good corporate governance, then this study will attempt to increase the effect of tax planning, good corporate governance proxy with institutional ownership on the value of the company.

\section{LITERATURE REVIEW}

\subsection{Agency Theory}

Agency theory or agency theory is a theory that states the existence of a 
working relationship between the party that gives the authority (principal) and the party that receives authority (agent) in the form of a partnership. Agency relations as a contract where one or more principals hire other people (agents), to do some services for their interests by delegating some authority to make decisions to agents. The separation of ownership and control of the company causes management to act in accordance with the wishes of the principal, thus giving rise to agency conflict. This conflict occurs because agents do not act to maximize the welfare of principals, but have a tendency to benefit the interests of individual agents at the expense of the interests of the owners (Winanto and Widayat, 2013).

\subsection{Signalling Theory}

Signal theory on the importance of information released by the company on investment decisions of parties outside the company. information that is important for shareholders, because information presents things that happen in the company both those that happened in the past, now, and predict future events. Moreover, knowing the stock market (Pratiwi and Suryanawa, 2014). Published information will signal to investors in decision making

\subsection{Tax}

Tax is a people's contribution to the state treasury based on the law (which can be imposed) by not receiving reciprocal services (contra) which can be directly shown and used to pay for public expenses.

\subsection{Tax Function}

1. Budgetair Function (State Financial Source)

This means that tax is one of the sources of government revenue to finance both routine and development expenditures.
2. Regularend function (regulator) Tax has a regulatory function, meaning tax as a tool to regulate or implement government policies in the social and economic fields and achieve certain objectives outside the financial field.

\subsection{Tax collection system}

1. Official Assessment System

Tax collection system that authorizes the tax apparatus to determine the amount of tax payable each year in accordance with applicable tax laws and regulations.

2. Self Assessment System

The tax collection system that authorizes Taxpayers to determine the amount of tax payable annually according to the applicable tax laws and regulations. Taxpayers are considered capable of calculating taxes, being able to understand current tax laws, and having high honesty, and being aware of the importance of paying taxes.

3. With holding system

Tax collection system that authorizes the appointed third party to determine the amount of tax owed by the taxpayer in accordance with applicable tax laws and regulations. Third party decisions are made according to tax laws, presidential decrees, and other regulations to cut and collect taxes, deposit, and account for through available taxation facilities.

\subsection{Tax Collection Terms}

1. Tax collection must be fair (Terms of Justice)

2. Tax collection must be based on law (judicial conditions) 
3. Does not interfere with the economy (Economic Terms)

4. Tax collection must be efficient (Financial Terms)

5. The collection system must be simple.

\subsection{Tax Collection Principle}

1. Principle of Domicile

(Principle of Residence)

This principle states that the state has the right to impose a tax on all income of taxpayers who reside in their territory, both income originating from within and outside the country. 2. Source Principle This principle states that the state has the right to impose a tax on income sourced in its territory without regard to the taxpayer's residence, every person who earns income from Indonesia is taxed on the income obtained earlier.

3. Nationality Principle This principle states that taxation is related to the nationality of a country. For example, foreign nation tax in Indonesia is imposed on anyone who is not Indonesian, but resides in Indonesia.

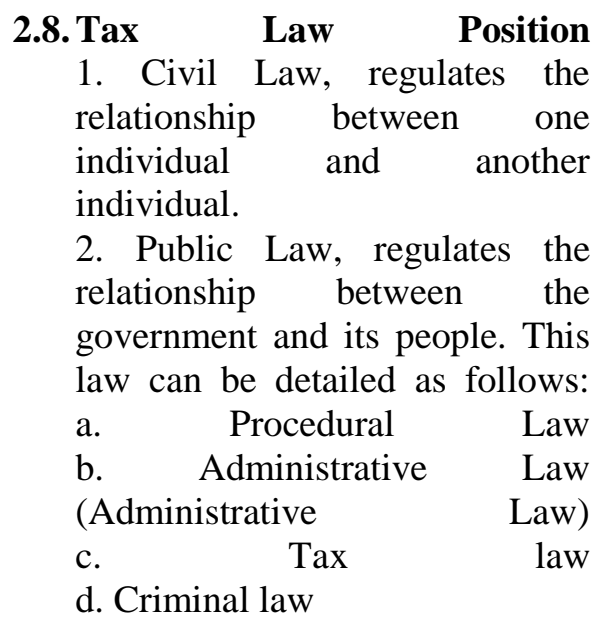

\section{RESEARCH METHOD}

\subsection{Research type}

This type of research is a type of descriptive quantitative research. The purpose is to develop systematic models, theories and hypotheses related to phenomena. According to Sugiyono (2016) quantitative research can be interpreted as a research method that is based on the philosophy of positivism, which is used to examine certain populations or samples, data collection using research instruments, data analysis is quantitative / statistical, with the aim of testing predetermined hypotheses.

\subsection{Research location}

The location of the study was conducted at the Indonesia Efef Exchange (IDX) for the period 2013-2017 with data obtained from the official website of the Indonesia Stock Exchange (IDX) in www.idx.co.id, because the type of manufacturing company manufacturing companies listed on the IDX must have done taxation activities so that it can be obtained the number of samples that represent and the results of research that are good in the statistical aspects.

\subsection{Variables and Measurements}

Variables are instructions on how a variable is measured, so researchers can know the good or bad of the measurement. So the research variable is an attribute or the nature or value of people, objects or activities that have certain variations set by the researcher to be studied and then conclusions drawn (Sugiyono, 2016) 


\subsection{Population}

According to Sugiyono (2016: 80) the opulation is a generalization area consisting of: objects / subjects that have certain qualities and characteristics set by researchers to be studied and then conclusions drawn. The population in this study are manufacturing companies listed on the Indonesia Stock Exchange Period 2013-2017.

\subsection{Sample}

1. The company is engaged in manufacturing which is listed on the Indonesia Stock Exchange in the period 2013-2017

2. Manufacturing companies that issue financial statements in a row during the period

2013-2017

3. Manufacturing companies that use rupiah currency units in financial statements for the period 2013-2017 4. Manufacturing companies that did not suffer losses during the study year 5. Financial reports that have complete information related to the variables studied in the period 2013-2017

\subsection{Data collection technique}

According to Sugiyono (2016: 224) Data collection technique is the most strategic step in research, because the purpose of research is to obtain data. Data collection can be done in various settings, various sources, and various ways. And there are four kinds of data collection techniques, namely observation, interview, documentation, and combination.

\subsection{Data analysis technique}

The data technique used is the quantitative analysis method. According to Sugiyono (2016: 8) quantitative research can be interpreted as a research method based on positivism philosophy, used to examine the pupulation and certain samples, data collection using research instruments, quantitative / statistical data analysis, with the aim of testing the predetermined hypothesis. The research used is the influence of Good Corporate Governance, the effect of Tax Planning, on Corporate Value, the analysis used is:

\section{RESULTS AND DISCUSSION}

\subsection{Overview of Research Objects}

The company chosen as the object of this research is a manufacturing company listed on the Indonesia Stock Exchange (IDX) in the period 2013 to 2017. Taken from the criteria selected based on purposive sampling from a population of 144 companies and from the criteria set by the author there are 24 who meet the criteria, because there are 3 companies that experience outliers because they are not normally distributed because the value is too high. Therefore the number of samples after outliers was 21 companies that met these criteria.

\subsection{Sample Description}

This study uses a purposive sampling method, which is a withdrawal method based on certain criteria. The detailed sample selection process will be presented in table 4.1. as follows :

\begin{tabular}{|c|l|l|l|}
\hline NO & \multicolumn{1}{|c|}{ Description } & Rejected & Accepted \\
\hline 1. & $\begin{array}{l}\text { The company is } \\
\text { engaged in } \\
\text { manufacturing } \\
\text { which is listed } \\
\text { on the Indonesia } \\
\text { Stock Exchange } \\
\text { (IDX) for the } \\
\text { period 2013- } \\
\text { 2017. }\end{array}$ & 144 \\
\hline 2. & $\begin{array}{l}\text { Manufacturing } \\
\text { companies that } \\
\text { publish } \\
\text { financial } \\
\text { statements in a } \\
\text { row during the } \\
\text { 2013-2017 }\end{array}$ & & \\
\hline
\end{tabular}




\begin{tabular}{|c|c|c|c|}
\hline & period & & \\
\hline 3. & $\begin{array}{l}\text { Manufacturing } \\
\text { companies that } \\
\text { use rupiah } \\
\text { currency units } \\
\text { in their financial } \\
\text { statements for } \\
\text { the period 2013- } \\
2017\end{array}$ & 21 & 75 \\
\hline 4. & $\begin{array}{l}\text { Manufacturing } \\
\text { companies that } \\
\text { did not suffer } \\
\text { losses during } \\
\text { the study year. }\end{array}$ & 30 & 45 \\
\hline 5. & $\begin{array}{l}\text { Financial } \\
\text { reports that } \\
\text { have complete } \\
\text { information } \\
\text { related to } \\
\text { variables } \\
\text { studied in the } \\
\text { period 2013- } \\
2017 \text { (as for } \\
\text { those that are } \\
\text { incomplete } \\
\text { because in the } \\
\text { KI proxy there } \\
\text { are those that } \\
\text { are not listed in } \\
\text { institutional } \\
\text { ownership) }\end{array}$ & 21 & 24 \\
\hline \multicolumn{2}{|c|}{$\begin{array}{l}\text { Data that } \\
\text { experiences outliers } \\
\text { (because data is not } \\
\text { normally distributed) }\end{array}$} & 3 & 21 \\
\hline \multicolumn{2}{|c|}{$\begin{array}{l}\text { Number of Samples } \\
\text { (after outliers) }\end{array}$} & \multicolumn{2}{|c|}{21 (Companies) } \\
\hline \multicolumn{2}{|c|}{ Time } & \multicolumn{2}{|c|}{5 (Years) } \\
\hline \multicolumn{2}{|c|}{$\begin{array}{l}\text { Total Research } \\
\text { Samples }\end{array}$} & \multicolumn{2}{|c|}{105 (Data) } \\
\hline
\end{tabular}

Based on the sample selection criteria the author obtained 21 (twenty one) manufacturing companies as the research sample using purposive sampling method, namely a sampling technique with criteria. For the period of observation taken by researchers as much as 5 years 2013-2017. The list of studies is as follows:

\begin{tabular}{|l|l|l|}
\hline No & Code & $\begin{array}{l}\text { Names of the company } \\
\text { Perusahaan/Emiten }\end{array}$ \\
\hline
\end{tabular}

\begin{tabular}{|l|l|l|}
\hline 1. & AMFG & Asahimas Flat Glass Tbk \\
\hline 2. & BUDI & $\begin{array}{l}\text { PT Budi Starch \& Sweetener } \\
\text { Tbk }\end{array}$ \\
\hline 3. & CPIN & $\begin{array}{l}\text { Charoen Pokphand } \\
\text { Indonesia Tbk }\end{array}$ \\
\hline 4. & DLTA & Delta Djakarta Tbk \\
\hline 5. & DPNS & Duta Pertiwi Nusantara Tbk \\
\hline 6. & EKAD & $\begin{array}{l}\text { Ekadharma International } \\
\text { Tbk }\end{array}$ \\
\hline 7. & GGRM & Gudang Garam Tbk \\
\hline 8. & IGAR & $\begin{array}{l}\text { Champion Pacific Indonesia } \\
\text { Tbk }\end{array}$ \\
\hline 9. & INDF & $\begin{array}{l}\text { Indofood Sukses Makmur } \\
\text { Tbk }\end{array}$ \\
\hline 10. & JECC & Jembo Kable Company Tbk \\
\hline 11. & KBLM & Kabelindo Murni Tbk \\
\hline 12. & KDSI & $\begin{array}{l}\text { Kedawung Setia Industri } \\
\text { Tbk }\end{array}$ \\
\hline 13. & MYOR & Mayora Indah Tbk \\
\hline 14. & RICY & Ricky Putra Globalindo Tbk \\
\hline 15. & ROTI & $\begin{array}{l}\text { Nippon Indosari Corpoindo } \\
\text { Tbk }\end{array}$ \\
\hline 16. & SKBM & Sekar Bumi Tbk \\
\hline 17 & SCCO & $\begin{array}{l}\text { Supreme Cable } \\
\text { Manufacturing Corporation } \\
\text { Tbk }\end{array}$ \\
\hline 18 & TCID & Mandom Indonesia Tbk \\
\hline 19 & TSPC & Tempo Scan Pasific Tbk \\
\hline 20 & UNVR & Unilever Indonesia Tbk \\
\hline 21 & WIIM & Wismilak Inti Makmur Tbk \\
\hline & & \\
\hline
\end{tabular}

\subsection{Descriptive Statistics Analysis}

Descriptive statistical analysis was used to provide a statistical description of the independent variables and the dependent variable in this study. These variables will be tested descriptively statistically. Testing with descriptive statistics will provide an overview or descriptive data through minimum, maximum, average, and standard deviation values.

The following are the results of the descriptive statistical test using SPSS 22: 


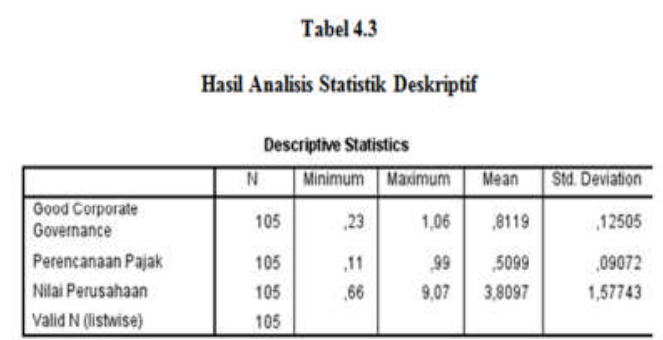

Sumber: data diolah menggunakan program SPSS versi 22

\subsection{The classic assumption test}

The classic assumption test is done to find out whether the data is worth analyzing. This study uses 4 (four) classic assumption tests, namely: a. Normality test

The normality test aims to test whether in the regression model, the interrupting or residual variables have a normal distribution. A good regression model is normally distributed. In this study the normality test is seen from the spread of data (points) to the normal Standarized Residual P-Plot Regression. The statistical test used is using the Kolmogorov-Smirnov (K-S) nonparametric test. The KolmogorovSmirnov (K-S) test is done by looking at the probability numbers.

\section{CONCLUSION}

1. Good Corporate Governance represented by proxy for institutional ownership (X_1) has a significant positive effect on firm value (Y), in manufacturing companies listed on the Indonesia Stock Exchange in 2013-2017, the results of this study are in line with Kusumaningtyas research (2015) stating that Institutional ownership has a significant effect on company value Because the greater the ownership of financial institutions, the greater the power of voice and the drive to optimize the value. of the company.

2. Tax Planning with ETR proxy (X_2) has a significant positive effect on firm value (Y), in manufacturing companies listed on the Indonesia Stock Exchange in 2013-2017, the results of this study are in line with Lestari (2014) and Yuono (2016) Influence significant positive Tax Planning Against Company Values. Found a positive relationship can be said managerial tax planning in order to increase the value of the company and the benefits obtained are greater than the cost or risk.

\section{Limitations}

1. Factors that influence the value of the company in this study consist of: Institutional Ownership, and ETR. 2. The company sampled only 21 companies with data obtained 105

3 . This research only takes 5 years, namely from 2013 to 2017 , so that the data taken is likely to not reflect the company's condition in the long run.

\section{Suggestion}

1. This research realizes there are still many for investors It is expected that the results of this study will be able to provide information about the effect of investment on firm value which is a variable in this study. 2. For Companies

It is expected that the results of this study will be useful for every company that exists. And the company should later increase the value of the company. 


\section{REFERENCES}

Andri Veno. (2015). Pengaruh Good Corporate Governance Terhadap Kinerja Perusahaan Pada Perusahaan Manufaktur Go Public (Studi Empiris pada Perusahaan yang Terdaftar di BEI (2011 Sampai 2013). BENEFIT Jurnal Manajemen dan Bisnis Volume 19, Nomor 1, hlm 95-112.

Danang, Sunyoto., (2016). Metode Penelitian Akuntansi

Hidayat, Muhammad dan Muhammad Imam Akbar Hairi. (2016). Pengaruh Perencanaan Pajak Terhadap Nilai Perusahaan Yang Terdaftar Di Bursa Efek Indonesia Periode 2009-2013. Jurnal Ilmiah Ekonomi Global Masakini, 7(2), pp: 23-29.

Ghozali, Imam., (2016). Aplikasi Analisis Multivariate dengan Program IBM SPSS 22 Semarang: Badan Penerbit Universitas Diponegoro.

Kusumaningtyas, T. K., (2015). Pengaruh Good Corporate Governance Terhadap Nilai Perusahaan Yang Terdaftar Pada Indeks Srikeheti. Jurnal Ilmu \& Riset Akuntansi.

Lestari, Nanik. Dan Ratna, Whardani. (2015). The Effect of the Tax Planning to Firm Value With Moderating Board Diversity, International Journal of Economics and Financial Issues, Vol 5, 315-323.

Mardiasmo, (2016). perpajakan, Yogyakarta, Andi Offset

Nainggolan, Subaraman Desmon Asa. Dan Listiadi, Agung. (2014). Pengaruh Kebijakan Hutang Terhadap Nilai Perusahaan Dengan Kebijakan Dividen. Jurnal Ilmu Manajemen, Vol 2, No. 3, 145-179.

Nike, Y., Zaitul dan Yunilma,. (2014). Pengaruh Perencanaan Pajak dan
Corporate Governance terhadap Nilai Perusahaan. e-Jurnal Bung Hatta, Volume 4

Pantaw. (2015). Analisis Pertumbuhan Penjualan, Ukuran Perusahaan, Return on Asset, dan Struktur Modal terhdap Nilai Perusahaan. Jurnal EMBA, 3(1), pp 961-971

Perdana, R. Z. P., (2014). Pengaruh Perencanaan Pajak dan Mekanisme Corporate Governance Terhadap Nilai Perusahaan. thesis.umy.ac.id.

Permatasari, L. W., \& Gayatri. (2016). Profitabilitas Sebagai Pemoderasi Pengaruh Good Corporate Governance Pada Nilai Perusahaan. E-Jurnal Akuntansi Universitas Udayana, 14(3).23072335.

Pratiwi, N., \& Suryanawa, I. K. (2014). Pengaruh Good Corporate Governance dan Corporate Social Responsibilty Disclosure Pada Return Saham. E-Jurnal Akuntansi Universitas Udayana, 9(2). 465-475.

Sartika, Dewi., (2015). Pengaruh Perencanaan Pajak Terhadap Nilai Perusahaan Dengan Kepemilikan Institusional Sebagai Pemoderasi Pada Perusahaan. Jurnal Ilmi \& Riset Akuntansi.

Samrotun, Y, C dan Suhendro., (2014). Strategi Perencanaan Pajak dalam Corporate Governance. 3rd Economics \& Business Research festival. PP. 1513-1542.

Simarmata, Permata., (2014). Pengaruh Tax Avoidance Jangka Panjang Terhadap Nilai Perusahaan Dengan Kepemilikan Institusional Sebagai Variabel Pemoderasi (Studi Empiris Pada Perusahaan Manufaktur yang Terdaftar Di BEI Periode 2011-2012). Skripsi. Program Sarjana Fakultas 
Ekonomika dan Bisnis Universitas Undayana, 646-673.

Siti, Resmi., (2014). Perpajakan Teori dan Kasus. Jakarta: Salemba Empat

Sugiyono. (2016). Metode Penelitian Pendidikan Pendekatan Kuantitatif, Kualitatif Dan R\&D. Bandung: Alfabeta.

Thaharah, Nina. (2016). Pengaruh Mekanisme Corporate Governance dan Kinerja Keuangan Terhadap Nilai
Perusahaan LQ 45. Jurnal Ilmu dan Riset Akuntansi: Volume 5, Nomor 2.

Winanto dan U. Widayat. (2013). Pengaruh Perencanaan Pajak dan Tata Kelola Perusahaan terhadap Nilai Perusahaan. Simposium Nasional Akuntansi XVI. Manado. Yuono, C. A., (2016). Pengaruh Perencanaan Pajak dan Corporate Governance Terhadap Nilai Perusahaan". Jurnal Ilmu dan Riset Akuntansi, 5, 1-19. 